\title{
PARTICIPATORY LAND USE PLANNING FOR COMMUNITY BASED FOREST MANAGEMENT IN SOUTH-EASTERN NIGERIA
}

\author{
By \\ Francis E. Bisong, Adebayo Animashaun \\ University of Calabar \\ and \\ Elizabeth Andrew-Essien Esekong \\ Cross River University of Technology, Calabar.
}

\begin{abstract}
SUMMARY
Paper examines the contribution and effectiveness of the community in land use planning decisions for sustainable forest management. Using participatory rural appraisal methodologies targeted at eight forest management committees (FMCs) and sixteen villages in the Cross River State, it highlights the structure of present and proposed community land uses in the context of community forest management, as well as evaluates the validity of these land use decisions. The result demonstrates that community land use decisions are valid and could constitute a reliable basis for community level forest management.
\end{abstract}

Keywords: Community, Forest Management, Participatory, Land Use, Planning.

\section{INTRODUCTION AND BACKGROUND}

Forest cover change statistics derived from recent satellite imageries for the Cross River region (Flasse 2002:3-20) show a growing tendency towards deforestation, forest degradation and fragmentation, while total deforested area between 1991 and 2001 increased by $22.5 \%$ for areas outside the Cross River National Park, degraded and fragmented forests increased by an astronomic $522 \%$. Greater loss was experienced in the community forest areas (29\%) than in the forest reserves (14\%). Agricultural expansion by small farmers and unsustainable logging remain the greatest direct threats to forest cover loss in the Cross River State, Nigeria.

The Flasse's report from which the data was derived was undertaken through the joint initiative and sponsorship of the Cross River State Forestry Commission (FC) and the DFID-Supported Cross River State Community Forestry Project (CRSCFP) in order to inform the development of forest management plans by communities in the Cross River State.

The management of forest by communities was explicitly recognized in the strategy document for the management of the Cross River State Forestry sector (FDD 1994:1-17) as the only viable option for the sustainable management of the Cross River forest. Community forest management in the Cross River State thus became operational in 1999 through the CRSCFP, which together with the FC facilitated the establishment and functioning of Forest Management Committees (FMCs). The FMCs were established by the traditional self-governing communities in the Cross River State, and represent the main community organs for articulating local level forest management decisions.

Land use plan was considered a major step towards the development of community based forest management plans. A participatory community land use survey was on the basis of this commissioned by the CRSCFP and FC. The essential input into the production of this plan was to be undertaken with the assistance and participation of the FMCs of the respective communities.

While doubts and cynicism may still be expressed in some quarters by policy makers and forest managers as to the capacity of communities to undertake rational land use planning that is technically feasible and 
scientifically valid to support decisions for sustainable forest management, there is a growing body of evidence and projects that attest to the success (despite some of their limitations) of community based forest and natural resource management decisions (Bisong 1998:1-44; Alden-wily et al 2000:36-45; Nolan 2001:231-235).

This paper highlights the essential attributes and results of community efforts at land use planning for community forest management in the Cross River State. It is a synthesis report based on facts obtained in facilitating the carrying out of eight (8) community based land use planning exercise for sixteen (16) communities and villages of the Cross River State between December 2000 and August 2002.

It focuses on:

1. Examining the profile and structure of present community land uses.

2. Highlighting the features of the proposed community land use plans to constitute the springboard for community management of forest resources.

3. Assessing the rationality or otherwise associated with given community land use decisions. 


\section{PARTICIPATORY LAND USE PLANNING AND COMMUNITY FOREST MANAGEMENT}

\section{Participatory Land Use Planning}

Land use planning simply put prescribes the forms and/or to what use individual parcels of land may be put on the basis of the social and economic needs of the community (Ajai 1999:111-121) and in accordance to their resource management objectives. It is usually designed to secure optimal utilization and development of the land in ways considered advantageous to the community dependent on it. The process entails a systematic assessment of land, its attributes, influences and alternatives for existing uses to achieve the most efficient use to which the land may be put (Igugu 1999:47-54) on the basis of collectively determined objectives.

The broader objective of land use planning is concerned with resolving conflicts generated by diverse interest from persons and activities seeking to make use of limited stock of land. Planning becomes imperative in controlling the pattern of land use in order to resolve conflicts and optimize benefits to be derived from the various user interests.

The two major hierarchies of land use planning long recognized are the official planning by public authorities and micro-planning where individuals owning land draw up plans to guide the development of such lands (Ajai 1999:111-121). Local or community participation in land use planning is new with respect to the two known hierarchies of planning. It represents a shift within the last three decades from the 'top down' approaches-official planning, to the 'bottom up' approaches-community based or participatory planning (BSP, 1993:47-87). As Umans (1998:22) observed, "it is a process which essentially aims at reversing the location of control from the external agency, extensionist or researcher to the villager as central actor". Participatory land use planning in the context of community management of natural resources thus involve a collective action by the local community to determine and decide on the best combination of land uses to serve mutually agreed goals for land development and conservation in accordance with the social and economic aspirations of the community.

Participatory Land Use Planning \& Resource Sustainability: Strategies to conserve tropical natural forests and rural resource complexes have been often centralized, based on procedure and approaches prescribed by forest and protected area management authorities. These have proved ineffective in arresting resource degradation problems thus, necessitating a shift towards participatory forms of forest planning and management. Despite the limitations of participation approaches and lack of consensus among resource managers and professionals as to the type and level of participation that should be encouraged on the basis of their perceived effectiveness, participatory initiatives in several community forest resource management projects attest to a number of positive attributes.

A Northern Thailand study (Sprung \& Huss 1998:1-5) called attention to the limitations of nonparticipatory approach to land classification schemes for watershed protection that relied entirely on biophysical criteria. This was alledged to restrict severely land use and settlement of the hill tribe peoples that had inhabited the area for centuries thus constraining significantly their livelihood sustenance efforts leading to resource use conflicts. A later application of participatory land use planning developed by the "Royal Forest Department and the University of Chaing Mai" that enabled local communities to assess and modify their land use systems in accordance with watershed management objectives, was found to yield promising results (Sprung \& Huss 1998:1-5).

A Kenyan based study posits that participatory land use planning provides the basis for incorporating the needs of all actual and potential land users in programs designed to resolve resource use conflicts, halt environmental degradation and rehabilitate degraded lands (Benjamin 2001:1-11). Appropriate choice and 
allocation of land use activities hinged on sustainability principles, and embarking on meaningful resource conservation efforts are possible after the needs of land users are satisfied. This is one valid strength of participatory land use planning.

Participatory Land Use Planning and Community Forest Management: Community based forest management is hinged on participatory planning principles. The links between both are inseparable. This is exemplified by the fact that conventional land use planning has been long recognized as the basic entry point that must preceed development of any site specific forest.

Conceptually speaking, community forestry as a terminology is used interchangeably with participatory forestry. Participatory forestry has been defined (FAO 2002:3-14) as a variety of terms used to describe sets of activities that involves "participation in forest management,... community forestry, community based forest management, social forestry, joint forest management, common property forest management, etc... it is an umbrella concept to cover all different types of forestry activities that involve local stakeholders especially villagers with different degrees of decision making authority".

While the catholicity provided by this definition allows for an all-inclusive understanding that serves to galvanize communities and countries with varied but worthy of note experience in participatory resource management ranging from traditional indigenous practices, international donor guided/ government supported experiences, to private forestry and local companies, some consider this to lack focus as well as create the problem of vagueness (FAO, 2000:2-14). Some clarification can thus be made at this point on the context of community participation applicable for the study. 


\section{COMMUNITY PARTICIPATION FRAMEWORK}

Community based forest management efforts are either self initiated or initiated by external agencies. They may, therefore, be viewed from the perspective of the actor/participant and external agent. ${ }^{16}$ Three typologies of community participation offered by the Biodiversity Support Program (1993:47-87) are:

1. Mobilization Strategy: where a project's plan for action is decided and designed by outsiders, usually through specialist within government or initiating donor organizations before local involvement commences. This is considered to have low prospects of sustainability.

2. Community Development Strategy: where surveys are carried our or meetings held to better appreciate community or institutional perceptions about a specific problem hitherto identified as a development constraint. Participatory techniques may then be applied to designing and maintaining specific initiatives or services to solve the problem. Under this typology, the community share some level of control with the external agent. Projects under this regime are capable of generating appreciable levels of community support as outputs may be in accordance with community-felt need.

3. Empowerment Strategy: where community-based groups, usually assisted by an outside facilitator initiate a learning and empowerment process that enables them define their goals and objectives. Communities often assume responsibility for their actions to meet defined objectives. The focus of control is with the participants. This strategy requires communities to design and implement their activities thus placing the highest level of control and responsibility with them. It is expected to yield potentially higher levels of sustainability.

A greater number of participation strategies fall within the mobilization and community development categories. The community forestry project in the Cross River State belongs in principle (design) to the highest typology-Empowerment strategy but in practice (implementation) it may be consigned to the second level-community development strategy. This is because the implementation of the strategy is largely a function of finding support from external agencies.

\section{THE SETTING}

Cross River State in South-Eastern Nigeria is a region of greatest biodiversity concentration in the country. Although occupying just $2.4 \%$ of the country's total land surface of $923,850 \mathrm{~km}^{2}$, its natural forest covers 924,957ha (FRS 1998:1-22), and represents a sizeable 31\% of the total remaining tropical moist forest in Nigeria (FDD 1994:1-17). The region is home to the Cross River National Park, a Wildlife Sanctuary, 14 Forest Reserves and a vast tract of forest under community control totaling about 303,522ha.

These forests are well stocked with economically useful trees, shrubs and climber species of timber and non-timber value (Dunn et al 1994:1-7) with considerable utility for the socio-economic sustenance of numerous communities within the region. The resources of the area have attracted a large influx of migrant population, labour, capital and infrastructure seeking to exploit the opportunities offered by the environment. With a total land area $0 \mathrm{f} 20,959 \mathrm{~km}^{2}$ and projected population of about 2.5 -million persons, population density is medium at 119 persons per $\mathrm{km}^{2}$. About 2,500 local communities inhabit the region (Atte 1996:1-30) and are heavily dependent on its natural resources for livelihood sustenance through activities such as small-scale agriculture, forest product collection and timber extraction. The above imposes intolerable pressure on forest resources, threatening sustainability. Resolving conflicting interest in land use through rational land use decisions that maximizes the gains of the relevant stakeholders at the grassroots hold the key to resource sustainability.

\section{METHOD}

This study was wholly participatory in approach. It adopted essentially the participatory learning and action (PLA), and participatory rural appraisal (PRA) methods. The PLA/PRA tools employed consisted of Participatory Mapping, Quantifying, Preference Ranking and Semi Structured Interviews (SSI). The participatory mapping methods were employed to determine and delineate community land uses such as 
vegetation and land use types, land units, landscape region, soils, watersheds, and land use plans. The SSI techniques were employed to characterize the various land use systems, while the quantifying/ preferenceranking techniques were employed to determine and quantify the proportion of community lands under the various land uses. To complement the PRA maps, the Global Positioning System (GPS) was used to delineate the vegetation land use boundaries of the community in their current and proposed forms. This was done with members of the community following, the basic lead provided by the PRA maps. The data derived from the GPS mapping for land use boundaries are reported for the study. This was supported by an indicative inventory to determine the vegetation type and distribution.

The forest management committee (FMC) was the main focal group of the study. The study is based on participatory land use survey (PLUS) output from Eight (8) Community FMCs out of the Ten (10) priorities FMCs for which the land use planning exercise was commissioned. The report therefore covers $80 \%$ of existing land use planning studies commissioned by the CRSCFP. FIGURE 1 is map of Cross River State showing the location of the FMCs and communities studied, while TABLE 1 provide details of FMCs and communities under focus.

The study proceeded by identifying, delineating and describing the community land uses through participatory mapping. The maps produced comprise the community land units, vegetation and land use types, soil and community land use plans. The mapping exercise made use of flip charts, cardboards, marker pens, and drawing and writing materials.

For each community the exercise proceeded by identifying a suitable site for the map drawing activities. After a brief explanation of the purpose of the activity and expected output, the mapping materials were presented to the FMC members. 


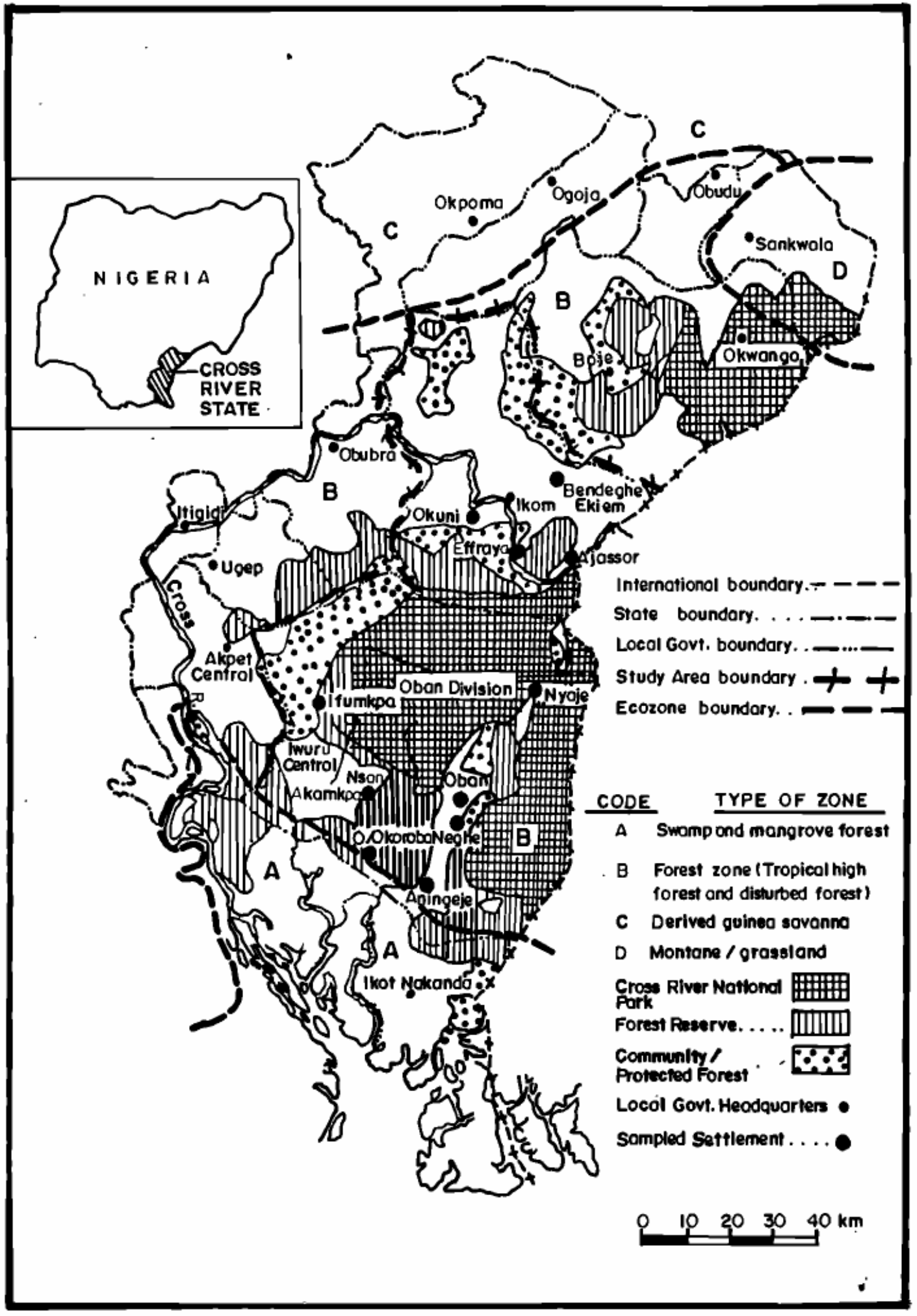

FIg. I : CROSS RIVER STATE SHOWING ECOLOGICAL ZONES, FOREST LAND-USE TYPES AND SAMPLED SETTLEMENTS 
Table 1: SURVEY COMMUNITIES \& FMCs

\begin{tabular}{|c|c|c|c|c|c|c|}
\hline $\mathrm{S} / \mathrm{n}$ & $\begin{array}{c}\text { FMCs/ } \\
\text { COMMUNITIES }\end{array}$ & $\begin{array}{c}\text { NO OF } \\
\text { SETTLEMENTS } \\
\text { VILLAGES }\end{array}$ & $\begin{array}{l}\text { SETTLEMENTS } \\
\text { VILLAGES }\end{array}$ & $\begin{array}{c}\text { POPULATION } \\
1996\end{array}$ & $\begin{array}{c}\text { LAND } \\
\text { AREA } \\
\mathrm{km}^{2}\end{array}$ & $\begin{array}{l}\text { SURVEY } \\
\text { PERIOD }\end{array}$ \\
\hline 1. & Okorshie & 1 & * Okorshie & 1275 & 26.24 & DEC, 2000 \\
\hline 2. & $\begin{array}{l}\text { Etara/Ekuri- } \\
\text { Eyeyeng }\end{array}$ & 2 & $\begin{array}{l}\text { *Etara } \\
\text { *Ekuri-Eyeyeng }\end{array}$ & $\begin{array}{l}562 \\
651\end{array}$ & 82.32 & $\begin{array}{l}\text { Feb, } 2001 \\
\text {-do- }\end{array}$ \\
\hline 3. & Agoi-Ekpo & 1 & *Agoi-Ekpo & $?$ & 49.32 & April, 2001 \\
\hline 4. & $\begin{array}{l}\text { Iko-Ekperem/ } \\
\text { Owai }\end{array}$ & 2 & $\begin{array}{l}\text { *Iko-Ekperem } \\
\text { *Owai }\end{array}$ & $?$ & 195.46 & $\begin{array}{l}\text { July, } 2001 \\
\text {-do- }\end{array}$ \\
\hline 5. & Nselle & 1 & Nselle & 1451 & 143.82 & DEC, 2001 \\
\hline 6. & Abo 1 & 3 & $\begin{array}{l}\text { *Abo Ogbagante } \\
\text { *Abo Emeh } \\
\text { *Abo Ebam }\end{array}$ & $\begin{array}{c}1316 \\
500 \\
1275\end{array}$ & 64.77 & $\begin{array}{c}\text { JAN, } 2002 \\
\text {-do- } \\
\text {-do- }\end{array}$ \\
\hline 7. & Abo Inland & 3 & $\begin{array}{l}* \text { Abo Obisu } \\
* \text { Abo Bonabe } \\
* \text { Abo Mkpang }\end{array}$ & $\begin{array}{l}539 \\
668 \\
751\end{array}$ & 77.24 & $\begin{array}{l}\text { Aug, } 2002 \\
\text {-do- } \\
\text {-do- }\end{array}$ \\
\hline 8. & Bashu & 3 & $\begin{array}{l}\text { *Kaku } \\
\text { *Bokim } \\
\text { *Okpambe }\end{array}$ & $\begin{array}{c}573 \\
- \\
750\end{array}$ & 26.55 & $\begin{array}{l}\text { Aug, } 2002 \\
\text {-do- } \\
\text {-do- }\end{array}$ \\
\hline No & 8 & 16 & & & & \\
\hline
\end{tabular}


The criteria adopted in classifying the land system and the actual and proposed land utilization types were as agreed by the FMC. The FMC members were divided into five groups. Each of the groups were required to map their impression of a specialized aspect of the land use such as land units, soils, current vegetation and land use, and the community hunting ground/ NTFP collection sites on the basis of the criteria collectively agreed to. The groups re-assembled after the exercise to present their various impressions. After a critical review of each of the focus groups' impression of the land systems and uses, two representatives from each of the groups were appointed by the group members to synthesize the various impressions collectively agreed into maps of specific land uses. The final map was represented in a plenary session of the FMC members for adjustments were necessary and final ratification. Occasional field checks were undertaken to confirm the group's impression of the community landscape.

\section{RESULTS AND DISCUSSION}

\section{Profile and Structure of Current Land Use Types}

TABLE 2 shows current land uses in the study settlements. Community lands as presently used is under high forest, secondary forest, savanna/ grassland, swamplands and farm/ fallow land. 51\% of overall land use is under tropical high forest from the total land area of $665.72 \mathrm{sq} \mathrm{km}$. The range is between $38 \%$ in Agoi-Ekpo community and 91\% in Etara/Ekuri-Eyeyeng communities. High forest is thus the dominant land use type in all communities studied. This is followed by the secondary forests and farm/ fallow lands which on the average account for $21.7 \%$ and $20.7 \%$ respectively of total land area. The grasslands, swamplands and planted forest are collectively less than $7 \%$ of total land area.

The forest as presently perceived serves many uses for the communities. These include its being the most important source of fertile farmlands, a source for the collection of most of the non-timber forest products (NTFPs) used for food, income, local craft, and medicine, a source for timber resources used for building and local construction a provider of ecological services such as protection of streams and rivers from drought cycles, and local climate regulation, a source of clean water, and the, provision of socio-cultural services such as burial sites for discarding mysterious deaths. In addition it harbors numerous tourism assets for many of the communities.

The secondary forest (areas exceeding 15 to 20years of regrowth) is valued for the collection of some important products such as piper guineense, Raphia venifera, Pleurotus tuberegium (Mushroom), Diallium guinensis, Xlopia aethiopica (Bush pepper), Ricennodendrum heudelottii (Njang-asang) Afromomum spp (Alligator pepper), Thaumantococcus danielli, (Wrapping leaf), Bambusa Vulgarins, etc, and many animal species such as Cutting grass, Giant rats, Bush pig etc. The Secondary Forest in Bashu community for instance serves as a refuge for the Bush pigs when escaping from predator species such as the Leopards or when disturbed by the migratory passage of the Elephants. Secondary forest is also valued as an important source of agricultural land as farm work is made easier in it than in the virgin forest.

The swamplands and grasslands are generally of limited area coverage. In Nselle where they constitute a sizeable proportion of the landscape, and in the Agoi-Ekpo, the swamplands are utilized for early farming before the rains set in for crops like rice, sugarcane, cocoa, okro, pepper and vegetables. Swamplands are a source of NTFP, such as Raphia palm (Raphia hookeria), wrapping leaf (Thaumatococcus danielli), Cane rope (Eramospartha marcrocarpa), Cotton tree (Ceiba pentandra) and Ebony (Diospyros spp). The grasslands are fairly sizeable in Nselle and are a source of Indian Bamboo (Bambusa Vulgarins), Date palm, mushroom and super grass. Their agricultural uses include the cultivation of yam, cashew, cassava, groundnut, maize and cowpea. 
TABLE 2: PROFILE AND STRUCTURE OF PRESENT LAND USE TYPES IN CROSS RIVER STATE

\begin{tabular}{|c|c|c|c|c|}
\hline $\mathbf{S} / \mathbf{n}$ & $\begin{array}{l}\text { Community/ } \\
\text { Settlement }\end{array}$ & Vegetation/ Land Use Type & Size sq km & $\begin{array}{c}\text { Proportion of Land Area } \\
\text { Covered (\%) }\end{array}$ \\
\hline \multirow[t]{6}{*}{1} & \multirow[t]{5}{*}{ Okorshie } & High Forest & 11.49 & 43.8 \\
\hline & & (Wood lands \& Palm Bush) & 4.00 & 15.3 \\
\hline & & Forest Plantation & 1.05 & 4.0 \\
\hline & & Grassland & 2.67 & 10.2 \\
\hline & & Farmland/Fallow & 7.03 & 26.8 \\
\hline & & Total Land Area & 26.24 & 100 \\
\hline \multirow[t]{3}{*}{2} & \multirow{3}{*}{$\begin{array}{l}\text { Etara/ Ekuri- } \\
\text { Eyeyeng }\end{array}$} & High Forest & 75.20 & 91.35 \\
\hline & & Secondary Forest & 2.19 & 2.66 \\
\hline & & Farm/Fallow & 4.93 & 6.00 \\
\hline & & Total Land Area & 83.32 & 100.00 \\
\hline \multirow[t]{5}{*}{3} & \multirow{4}{*}{$\begin{array}{l}\text { Agoi-Ekpo } \\
\text { (Tekowa) }\end{array}$} & High Forest & 18.89 & 38.30 \\
\hline & & Secondary Forest & 18.73 & 37.98 \\
\hline & & Swamp Land & 1.71 & 3.47 \\
\hline & & Farm/Fallow & 9.99 & 20.25 \\
\hline & & Total Land Area & 49.32 & 100.00 \\
\hline \multirow[t]{4}{*}{4} & \multirow[t]{3}{*}{ Iko-Ekperem/ Owai } & High Forest & 89.25 & 45.66 \\
\hline & & Secondary Forest & 52.67 & 26.95 \\
\hline & & Farm/Fallow & 53.54 & 27.39 \\
\hline & & Total Land Area & 195.46 & 100 \\
\hline \multirow[t]{6}{*}{5} & \multirow[t]{5}{*}{ Nselle } & High Forest & 51.59 & 35.87 \\
\hline & & Secondary Forest & 31.12 & 21.64 \\
\hline & & Derived Savanna/Grassland & 20.61 & 14.32 \\
\hline & & Swampland & 18.60 & 12.93 \\
\hline & & Farm/Fallow & 21.90 & 15.22 \\
\hline & & Total Land Area & 143.82 & 100.00 \\
\hline \multirow[t]{5}{*}{6} & \multirow[t]{4}{*}{ Abo 1} & High Forest & 34.49 & 53.25 \\
\hline & & Secondary Forest & 13.33 & 20.58 \\
\hline & & Swamp Land & 1.00 & 1.54 \\
\hline & & Farm/ Fallow & 15.21 & 24.63 \\
\hline & & Total Land Area & 64.77 & 100.00 \\
\hline \multirow[t]{3}{*}{7} & \multirow[t]{3}{*}{ Abo Inland } & High Forest & 44.81 & 58.01 \\
\hline & & Secondary Forest & 17.22 & 22.29 \\
\hline & & Farm/ Fallow & 15.21 & 19.69 \\
\hline
\end{tabular}




\begin{tabular}{|c|c|c|c|c|}
\hline $\mathbf{S} / \mathbf{n}$ & $\begin{array}{l}\text { Community/ } \\
\text { Settlement }\end{array}$ & Vegetation/ Land Use Type & Size sq km & $\begin{array}{c}\text { Proportion of Land Area } \\
\text { Covered (\%) }\end{array}$ \\
\hline & & Total Land Area & 77.24 & 100.00 \\
\hline \multirow[t]{4}{*}{8} & \multirow[t]{3}{*}{ Bashu } & High Forest & 11.95 & 45.00 \\
\hline & & Secondary Forest & 5.16 & 19.44 \\
\hline & & Farm/ Fallow & 9.44 & 35.55 \\
\hline & & Total Land Area & 26.55 & 100.00 \\
\hline \multirow[t]{7}{*}{9} & \multirow[t]{6}{*}{ All Communities } & High Forest & 337.67 & 50.72 \\
\hline & & Secondary Forest \& Woodlands & 144.42 & 21.69 \\
\hline & & Derived Savanna/ Grassland & 23.28 & 3.50 \\
\hline & & Swampland & 21.31 & 3.20 \\
\hline & & Forest plantation & 1.05 & 0.16 \\
\hline & & Farm/ Fallow & 137.99 & 20.73 \\
\hline & & Grand Total & 665.72 & 100.00 \\
\hline
\end{tabular}

SOURCE: AUTHOR'S FIELD SURVEY, 2000-2002 


\section{Profile and Structure of the Proposed Community Land Use Plan}

Communities are evolving land use plans to counter various forms of resource abuse and as a first step towards sustainable community forest management. These are generally in the context of allocating community land areas for forest reserve/ protection, timber exploitation, multipurpose tree crop development zones, areas for agricultural expansion, watershed protection and a number of other uses.

Despite commonalities in the proposed land use plans, communities differ with respect to land use allocations. This is usually in accordance to community socio-economic imperatives and environmental protection considerations. TABLE 3 shows the general and community specific details in the types and structure of the proposed land use plan, while FIGURE 2 highlights the major components of the general structure of community land use plan.

A total of eighteen different land uses are reflected in the plan from the perspective of the overall picture (TABLE 3). Some communities propose to use their land in six different ways while others have up to ten use types. The dominant forms of land use revealed in the plan are community forest reserve $(18.54 \%$ of land area), timber harvesting (14.14\%), farm expansion area (23.07\%), and area presently used as farmland $(20.08 \%)$. These four use types account for $75.33 \%$ of total land coverage of the proposed plan. Other fairly significant use types with respect to the overall picture are multipurpose tree crop development and forest plantation zones accounting respectively for $7.15 \%$ and $5.82 \%$ of total land area. 
Quality Education Imperatives for Inclusive Basic Education 253

TABLE 3: PROFILE AND STRUCTURE OF PROPOSED COMMUNITY LAND USE PLAN FOR FOREST MANAGEMENT CROSS-RIVER STATE. 


\begin{tabular}{|c|c|c|c|c|c|c|c|c|c|c|c|c|c|c|c|c|c|c|}
\hline \multirow[b]{2}{*}{ LAND USE PLAN } & \multicolumn{2}{|c|}{ OKORSHIE } & \multicolumn{2}{|c|}{$\begin{array}{c}\text { ETARA/ } \\
\text { LWEFIEY ENWCGal }\end{array}$} & \multicolumn{2}{|c|}{$\begin{array}{c}\text { AGOI-EKPO } \\
f \text { Contemporary Re }\end{array}$} & \multicolumn{2}{|c|}{$\begin{array}{l}\text { IKO/ OWAI } \\
\text { search }\end{array}$} & \multicolumn{2}{|c|}{ NSELLE } & \multicolumn{2}{|c|}{$\mathrm{ABO} 1$} & \multicolumn{2}{|c|}{$\begin{array}{c}\text { ABO } \\
\text { INLAND }\end{array}$} & \multicolumn{2}{|c|}{ BASHU } & \multicolumn{2}{|c|}{$\begin{array}{l}\text { OVERALL } \\
\text { PICTURE }\end{array}$} \\
\hline & $\hat{\beta} \frac{\pi}{\pi}$ & 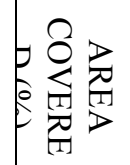 & 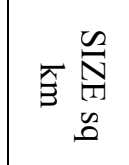 & 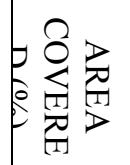 & $\overrightarrow{\widehat{B}} \underset{\substack{N \\
\tilde{n}}}{\stackrel{n}{n}}$ & 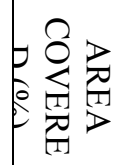 & 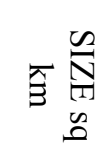 & 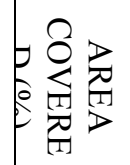 & 즐 $\frac{\pi}{N}$ & 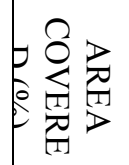 & 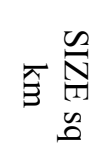 & 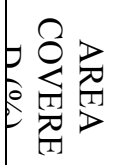 & त्रे & 党 & 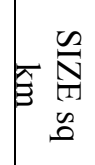 & 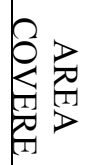 & 즐 & 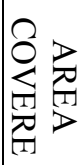 \\
\hline $\begin{array}{l}\text { Community Forest } \\
\text { Reserve }\end{array}$ & $\begin{array}{c}7.5 \\
0\end{array}$ & 28.58 & 23.14 & 23.11 & 1.24 & 2.51 & 31.05 & 15.88 & 23.26 & 16.17 & 17.59 & 27.16 & 18.28 & 23.67 & $\begin{array}{c}1.3 \\
8\end{array}$ & $\begin{array}{c}5.2 \\
0\end{array}$ & $\begin{array}{c}123.4 \\
4\end{array}$ & $\begin{array}{c}18.5 \\
4\end{array}$ \\
\hline Timber Harvesting & - & - & 7.52 & 9.14 & 2.11 & 4.28 & 27.09 & 13.88 & 26.57 & 18.47 & 6.72 & 10.88 & 16.16 & 20.92 & $\begin{array}{c}7.9 \\
9\end{array}$ & $\begin{array}{l}30 . \\
10\end{array}$ & 94.16 & 14.4 \\
\hline $\begin{array}{l}\text { Multipurpose Tree } \\
\text { Crop Dev }\end{array}$ & $\begin{array}{c}0.6 \\
2\end{array}$ & 2.36 & 18.36 & 22.30 & 5.44 & 11.03 & 20.74 & 10.61 & - & - & 2.05 & 3.17 & - & - & $\begin{array}{c}0.3 \\
9\end{array}$ & $\begin{array}{c}1.4 \\
7\end{array}$ & 47.6 & 7.15 \\
\hline Forest Plantation & $\begin{array}{c}1.0 \\
5\end{array}$ & 4.00 & - & - & 5.9 & 11.96 & 20.23 & 10.35 & 4.25 & 2.95 & 3.22 & 4.17 & 4.12 & 5.33 & - & - & 38.77 & 5.82 \\
\hline $\begin{array}{l}\text { Watershed Proct/ } \\
\text { Regeneration }\end{array}$ & $\begin{array}{c}2.6 \\
0\end{array}$ & 9.91 & + & + & - & - & - & - & - & - & - & - & + & + & $\begin{array}{c}0.1 \\
7\end{array}$ & $\begin{array}{c}0.6 \\
4\end{array}$ & 2.77 & 0.42 \\
\hline $\begin{array}{l}\text { Eco-Tourism Dev } \\
\text { Zone }\end{array}$ & - & - & + & + & - & - & - & - & - & - & 0.65 & 1.00 & 3.52 & 4.55 & - & - & 4.17 & 0.63 \\
\hline Wildlife Mang. Zone & - & - & - & - & 2.38 & 4.62 & - & - & - & - & 9.94 & 15.35 & - & - & - & - & 12.32 & 1.85 \\
\hline $\begin{array}{l}\text { Agric Plantation } \\
\text { (Multipurpose) }\end{array}$ & - & - & - & - & - & - & - & - & - & - & - & - & 2.64 & 3.41 & $\begin{array}{c}0.7 \\
1\end{array}$ & $\begin{array}{c}2.6 \\
7\end{array}$ & 3.35 & 0.50 \\
\hline Palm Plantation & - & - & - & - & 6.9 & 13.99 & - & - & 11.61 & 8.07 & - & - & - & - & - & - & 18.51 & 2.78 \\
\hline Cocoa Plantation & - & - & - & - & - & - & 5.56 & 2.84 & - & - & - & - & - & - & - & - & 5.56 & 0.84 \\
\hline Cashew Plantation & - & - & - & - & - & - & - & - & 10.57 & 7.35 & - & - & - & - & - & - & 10.57 & 1.59 \\
\hline $\begin{array}{l}\text { Forest For NTFP } \\
\text { Management }\end{array}$ & - & - & 12.07 & 14.66 & + & + & - & - & - & - & - & - & - & - & - & - & 12.07 & 1.81 \\
\hline Fish Pond Dev & - & - & - & - & 0.37 & 0.75 & - & - & 1.76 & 1.22 & 1.17 & 1.81 & - & - & $\begin{array}{c}0.1 \\
2\end{array}$ & $\begin{array}{c}0.4 \\
5\end{array}$ & 3.42 & 0.51 \\
\hline Wildlife Nurs. & - & - & 0.25 & 0.30 & - & - & - & - & - & - & - & - & - & - & - & - & 0.25 & 0.04 \\
\hline Pigery Dev & - & - & - & - & 1.01 & 2.05 & - & - & - & - & - & - & - & - & - & - & 1.01 & 0.15 \\
\hline Inventory Plot & - & - & 0.5 & 0.30 & - & - & - & - & - & - & - & - & - & - & - & - & 0.5 & 0.08 \\
\hline Farm Expansion & $\begin{array}{c}7.2 \\
4\end{array}$ & 27.59 & 15.55 & 18.88 & 3.20 & 6.49 & 40.85 & 20.90 & 52.93 & 36.80 & 7.65 & 11.81 & 19.56 & 25.32 & $\begin{array}{c}6.6 \\
4\end{array}$ & $\begin{array}{c}25 . \\
01\end{array}$ & $\begin{array}{c}153.6 \\
2\end{array}$ & $\begin{array}{c}23.0 \\
7\end{array}$ \\
\hline Present Farmland & $\begin{array}{c}7.2 \\
3\end{array}$ & 27.55 & 4.93 & 5.00 & 20.77 & 42.11 & 49.94 & 25.54 & 12.93 & 8.98 & 15.78 & 24.36 & 12.96 & 16.79 & $\begin{array}{c}9.1 \\
5\end{array}$ & $\begin{array}{l}34 . \\
46\end{array}$ & $\begin{array}{c}133.6 \\
9\end{array}$ & $\begin{array}{c}20.0 \\
8\end{array}$ \\
\hline TOTAL & $\begin{array}{l}26 . \\
24\end{array}$ & $100 \%$ & 82.32 & 100 & 49.32 & 100 & $\begin{array}{c}195.4 \\
6\end{array}$ & 2300 & $\begin{array}{c}143.8 \\
2\end{array}$ & 100 & 64.77 & 100 & 77.24 & 100 & $\begin{array}{l}26 . \\
55\end{array}$ & 100 & $\begin{array}{c}665.7 \\
2\end{array}$ & 100 \\
\hline
\end{tabular}


Quality Education Imperatives for Inclusive Basic Education

SOURCE: AUTHORS'S FIELD SURVEY, 2000-2002 
Fig 2: Structure of Community Land Use Plan in Cross River State (Percentage of Land Area Covered)

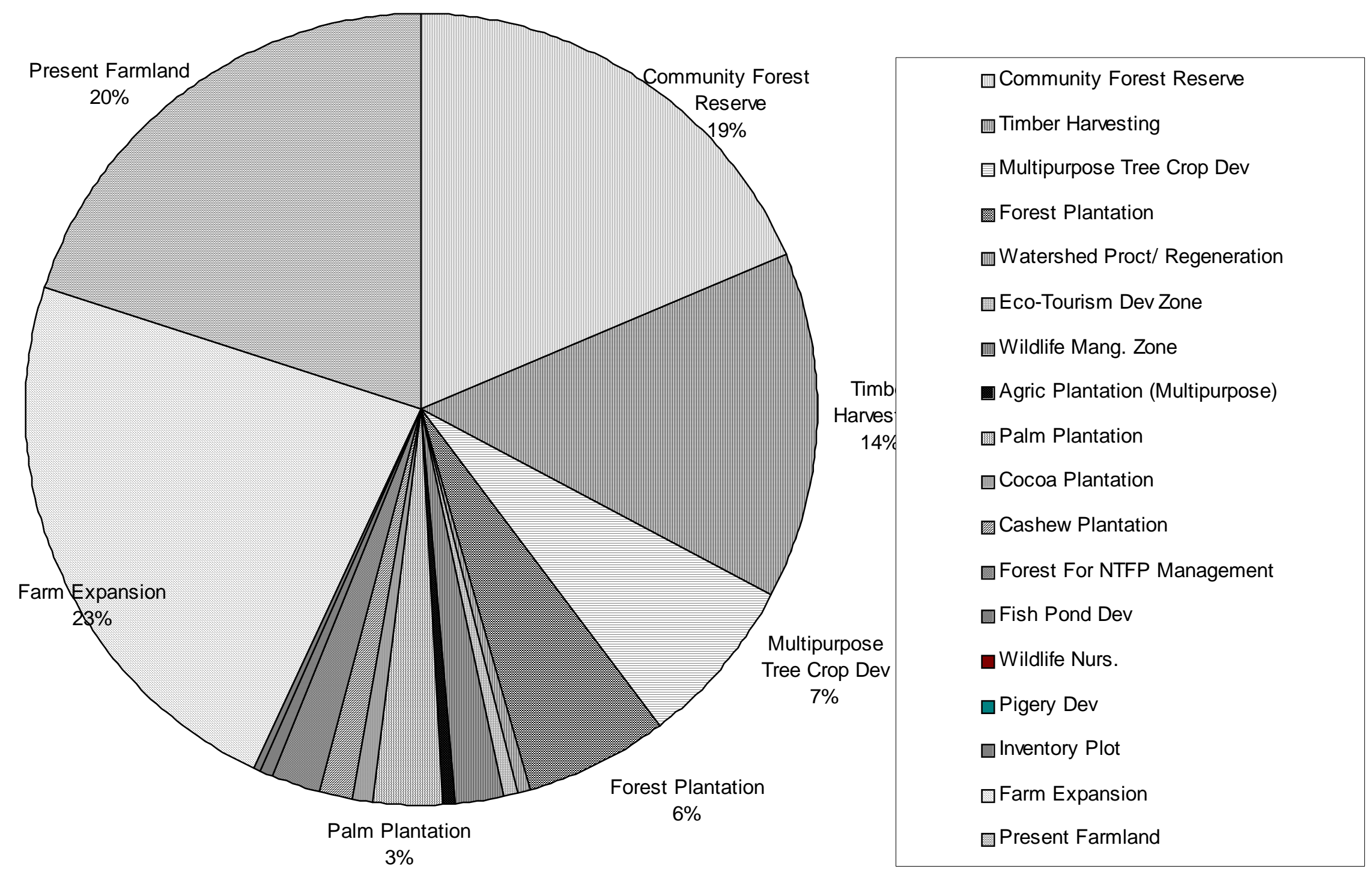


A number of the land use types appear not to be significant in the context of the general picture because they are confined only in a few of the communities where they may in some cases have an appreciable level of significance. An example is the zone for the management of Non-Timber Forest Products (NTFPs) found largely in Etara/ Ekuri Eyeyeng community where it occupies a whooping $12.07 \mathrm{sq} \mathrm{km}$ of land area and accounting for $14.66 \%$ of total land coverage (TABLE 3 ). The point to note is that the general picture should not diminish the significance of place specific realities. Some components of the plan such as fishponds by their nature do not require very large areas. Their significance may therefore not be assessed on the basis of total land coverage. Fishpond for instance is part of the land use plan of four out of eight of the communities investigated and may be regarded as a significant component of the community land use plan despite its insignificant area coverage of $3.42 \mathrm{sq} \mathrm{km}$ out of the total land area of $665.72 \mathrm{sq} \mathrm{km}$.

\section{Assessment of Community Land Use Decisions}

A qualitative assessment of community land use decisions is made to determine the rationality or otherwise of the proposed use plan. The criteria adopted are the source from which the proposed plan is derived with respect to the vegetation type, status of the vegetation, land unit or landscape region of the specific plan, and soil fertility status. The appropriateness of the location may be made on the basis of the suitability of the land type for the given use plan. This analysis is made only for the major components of the land use plan for brevity of space.

TABLE 4 is a chart showing the relationship between the specific major components of the plan (Community Forest Reserve, Timber Harvesting and Agricultural Expansion Zone) and the corresponding biophysical attributes of the underlying land types. From the table, the location of the community forest reserves in all of the eight communities justify the rationality of native wisdom in land use decisions. The reserves were essentially sourced from the high forest richly or moderately stocked in with abundant, common or frequently occurring NTFPs and timber species of merchantable sizes. Only in the IkoEkperem/ Owai community was the area allocated as forest reserve a degraded two storeyed canopy of low stocking in NTFP and timber species. The rationality in this decision however is to allow for the natural regeneration of the forest. A high level appreciation of the environmental protection attributes of keeping forest intact which underlies the reason for communities having a forest reserve site is also evident by an average of $18.5 \%$ of total community lands left intact to preserve the pristine attributes of the rain forest. This is yet to be felt in Agoi-Ekpo and Bashu communities with only $2.5 \%$ and $5 \%$ respectively of total lands kept intact as forest reserves. The environmental services provided by most of the reserves are as watershed protection sites for village streams and rivers.

One of the strongest justification and rationale for the reserve sites are in the attributes of their underlying land units or terrain. They are all located in extremely rugged terrain of high hills, mountain regions, steep and precipitous slopes, valley like depressions, undulating lands liable to flooding with water logging problems, etc. The areas could neither be used for productive agriculture or logging due to terrain constraints and as such are better left intact and protected from degradation to avoid ecological disruptions.

In the same vein, the areas allocated for timber exploitation on sustained yield principles and that for agricultural expansion are justified on many counts. Timber harvesting areas are richly endowed with common, frequent and in some cases abundantly occurring species of timber and NTFP value. Timber exploitation zones are largely sourced from the high forest and in some cases combined with the secondary forest. The land units are generally level or gently undulating, which allows for feasible exploitation of wood resources. 
TABLE 4: SUMMARY OF LANDSCAPE APPRECIATION \& ASSESSMENT FOR MAJOR COMPONENTS OF PROPOSED LAND USE PLAN IN CROSS-RIVER STATE

\begin{tabular}{|c|c|c|c|c|c|c|c|c|c|}
\hline $\begin{array}{c}\mathrm{S} / \\
\mathrm{n}\end{array}$ & $\begin{array}{l}\text { COMPON } \\
\text { ENTS OF } \\
\text { LAND } \\
\text { USE PLAN }\end{array}$ & OKORSHIE & ETARA/EYEYENG & AGOI-EKPO & IKO-OWAI & NSELLE & $\mathrm{ABO} 1$ & $\begin{array}{c}\text { ABO } \\
\text { INLAND }\end{array}$ & BASHU \\
\hline 1 & \multicolumn{9}{|c|}{ COMMUNITY FOREST RESERVE } \\
\hline & Size & $7.28 \mathrm{sq} \mathrm{km}(28.5 \%)$ & $23.14 \mathrm{sq} \mathrm{km} \mathrm{(28 \% )}$ & $1.24 \mathrm{sq} \mathrm{km}(2.51 \%)$ & $\begin{array}{c}31.05 \mathrm{sq} \mathrm{km} \\
\quad(15.8 \%)\end{array}$ & $\begin{array}{l}23.26 \mathrm{sq} \mathrm{km} \\
(16 \%)\end{array}$ & $\begin{array}{l}17.6 \mathrm{sq} \mathrm{km} \\
(27 \%)\end{array}$ & $\begin{array}{c}18.3 \mathrm{sq} \mathrm{km} \\
23.7 \%)\end{array}$ & $\begin{array}{l}1.4 \mathrm{sq} \mathrm{km} \\
(5 \%)\end{array}$ \\
\hline & Source & High Forest & High Forest & High Forest & High Forest & High Forest & High Forest & High Forest & High Forest \\
\hline & $\begin{array}{c}\text { Vegetation } \\
\text { Status }\end{array}$ & $\begin{array}{l}\text { Mod. NTFPs \& } \\
\text { timber stocking } \\
\text { waters shed, severe } \\
\text { threat of fire. }\end{array}$ & $\begin{array}{l}\text { Mod. Stocking of } \\
\text { timber \& NTFPs, major } \\
\text { watersheds. }\end{array}$ & $\begin{array}{l}\text { Well stocked with } \\
\text { NTFP/ timber } \\
\text { species. }\end{array}$ & $\begin{array}{l}\text { Degraded } 2 \\
\text { storeyed forest, low } \\
\text { stocking of timber } \\
\text { \& NTFP. }\end{array}$ & $\begin{array}{l}\text { Stocked with } \\
\text { timber species. }\end{array}$ & $\begin{array}{l}\text { Well } \\
\text { stocked with } \\
\text { timber/NTF } \\
\mathrm{P} \quad \text { species } \\
\text { source of } \\
\text { streams. }\end{array}$ & $\begin{array}{l}\text { Thickly } \\
\text { forested } \\
\text { stocked with } \\
\text { timber/ } \\
\text { NTFP } \\
\text { species. }\end{array}$ & $\begin{array}{l}\text { Well } \\
\text { stocked with } \\
\text { NTFP/ } \\
\text { timber } \\
\text { species. }\end{array}$ \\
\hline & $\begin{array}{l}\text { LAND } \\
\text { UNIT }\end{array}$ & $\begin{array}{lr}\text { Rugged } & \text { terrain } \\
\text { steep/ } / & \text { precipitous } \\
\text { slopes. } & \end{array}$ & $\begin{array}{l}\text { Rugged terrain, steep } \\
\text { valleys, strongly } \\
\text { undulating, high hills. }\end{array}$ & $\begin{array}{l}\text { Small hills wet or } \\
\text { dry valley-like } \\
\text { depressions. }\end{array}$ & $\begin{array}{l}\text { Strongly } \\
\text { undulating, high } \\
\text { hills, steep valleys. }\end{array}$ & $\begin{array}{l}\text { Gently } \\
\text { undulating. }\end{array}$ & $\begin{array}{l}\text { Hill/ steep } \\
\text { valleys \& } \\
\text { undulating } \\
\text { lands. }\end{array}$ & $\begin{array}{l}\text { Gently } \\
\text { sloping low } \\
\text { lands/ hills. }\end{array}$ & $\begin{array}{l}\text { Hills/ steep } \\
\text { valleys. }\end{array}$ \\
\hline & $\begin{array}{c}\text { SOIL/ } \\
\text { AGRIC. } \\
\text { POTENTIA } \\
\text { L }\end{array}$ & $\begin{array}{l}\text { Not cultivated; } \\
\text { difficult terrain. }\end{array}$ & $\begin{array}{l}\text { Mod soil fertility, Not } \\
\text { suitable for farming, } \\
\text { difficult terrain. }\end{array}$ & $\begin{array}{l}\text { Rarely cultivated; } \\
\text { flood \& erosion } \\
\text { problems. }\end{array}$ & $\begin{array}{l}\text { High fertility soils, } \\
\text { not cultivated } \\
\text { difficult terrain. }\end{array}$ & $\begin{array}{l}\text { Best soils, Not } \\
\text { cultivated } \\
\text { flooding \& water } \\
\text { loggings. }\end{array}$ & $\begin{array}{ll}\text { Rocky } & \text { soils, } \\
\text { little agric } \\
\text { value. }\end{array}$ & $\begin{array}{l}\text { Rocky soils; } \\
\text { limited } \\
\text { value to } \\
\text { agriculture. }\end{array}$ & $\begin{array}{l}\text { Fertile soils, } \\
\text { rugged/ hilly } \\
\text { terrain; little } \\
\text { cultivation. }\end{array}$ \\
\hline \multirow[t]{4}{*}{2} & \multicolumn{9}{|c|}{ TIMBER HARVESTING } \\
\hline & Area Size & NIL & $7.5 \mathrm{sq} \mathrm{km}(9.14 \%)$ & $2 \mathrm{sq} \mathrm{km}(4 \%)$ & $27 \mathrm{sq} \mathrm{km}(13.8 \%)$ & $\begin{array}{c}26.6 \mathrm{sq} \mathrm{km} \\
(18.5 \%)\end{array}$ & $\begin{array}{l}6.7 \mathrm{sq} \mathrm{km} \\
\quad(11 \%)\end{array}$ & $\begin{array}{c}16.2 \mathrm{sq} \mathrm{km} \\
(21 \%)\end{array}$ & $\begin{array}{l}8 \mathrm{sq} \mathrm{km} \\
(30 \%)\end{array}$ \\
\hline & Source & NIL & High/ Sec Forest & High Forest & High Forest & High Forest & High Forest & $\begin{array}{c}\text { High/ Sec } \\
\text { Forest }\end{array}$ & High Forest \\
\hline & $\begin{array}{c}\text { Vegetation } \\
\text { Status }\end{array}$ & - & $\begin{array}{l}\text { Mod. Stocking with } \\
\text { timber/ NTFP species. }\end{array}$ & 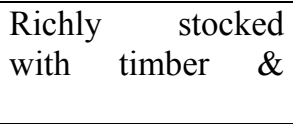 & $\begin{array}{l}\text { Well Stocked with } \\
\text { timber / NTFP }\end{array}$ & $\begin{array}{lr}\text { Stocked } & \text { with } \\
\text { timber/ } & \text { NTFP } \\
\text { species. } & \text { Closed } \\
\end{array}$ & $\begin{array}{l}\text { Stocked } \\
\text { with NTFP/ } \\
\text { timber }\end{array}$ & $\begin{array}{l}\text { Forest richly } \\
\text { stocked with } \\
\text { NTFP }\end{array}$ & $\begin{array}{l}\text { Richly } \\
\text { stocked with } \\
\text { NTFP/ }\end{array}$ \\
\hline
\end{tabular}




\begin{tabular}{|c|c|c|c|c|c|c|c|c|c|}
\hline & & & & NTFP species. & species & canopy forest. & $\begin{array}{l}\text { species. } \\
\text { Closed } \\
\text { canopy } \\
\text { forest. }\end{array}$ & $\begin{array}{l}\text { timber } \\
\text { species. }\end{array}$ & $\begin{array}{l}\text { timber } \\
\text { species. }\end{array}$ \\
\hline & $\begin{array}{l}\text { LAND } \\
\text { UNIT }\end{array}$ & - & $\begin{array}{l}\text { Gently Undulating } \\
\text { lands }\end{array}$ & Level lands & $\begin{array}{l}\text { Small hills \& } \\
\text { undulating lands }\end{array}$ & Level lands & Level lands & Level lands & Level lands \\
\hline & $\begin{array}{c}\text { SOIL/ } \\
\text { AGRIC } \\
\text { POTENTIA } \\
L\end{array}$ & - & $\begin{array}{l}\text { Mod. Fert; Cultivable } \\
\text { Lands. }\end{array}$ & $\begin{array}{l}\text { Mod. Fert; } \\
\text { Cultivatable Lands. }\end{array}$ & $\begin{array}{l}\text { Very Fertile lands. } \\
\text { Cultivable but } \\
\text { prone to erosion. }\end{array}$ & $\begin{array}{l}\text { Moderate } \\
\text { fertility; } \\
\text { cultivable lands. }\end{array}$ & $\begin{array}{l}\text { Mod. } \\
\text { Fertility } \\
\text { Cultivable } \\
\text { lands. }\end{array}$ & $\begin{array}{l}\text { Mod. } \\
\text { Fertility: } \\
\text { cultivable } \\
\text { lands. }\end{array}$ & $\begin{array}{l}\text { Fertile land: } \\
\text { cultivable. }\end{array}$ \\
\hline 3 & \multicolumn{9}{|c|}{ FARM EXPANSION AREA } \\
\hline & Size & $7.2 \mathrm{sq} \mathrm{km}(27.6 \%)$ & $16.6 \mathrm{sq} \mathrm{km}(20 \%)$ & $3.2 \mathrm{sq} \mathrm{km}(6.5 \%)$ & 40.9 sq km $(24.9 \%)$ & $\begin{array}{c}52.9 \mathrm{sq} \mathrm{km} \\
(37.6 \%)\end{array}$ & $\begin{array}{l}7.6 \mathrm{sq} \mathrm{km} \\
(12 \%)\end{array}$ & $\begin{array}{l}20 \mathrm{sq} \mathrm{km} \\
(25 \%)\end{array}$ & $\begin{array}{l}6.6 \mathrm{sq} \mathrm{km} \\
(25 \%)\end{array}$ \\
\hline & Source & $\begin{array}{l}\text { Savanna/ Wood } \\
\text { Lands }\end{array}$ & High Forest & High Forest & High Sec. Forest & $\begin{array}{l}\text { Savanna/ } \\
\text { Grassland }\end{array}$ & High Forest & $\begin{array}{l}\text { High/ Sec } \\
\text { forest \& } \\
\text { fallow }\end{array}$ & $\begin{array}{l}\text { Climate Sec } \\
\text { Forest }\end{array}$ \\
\hline & $\begin{array}{l}\text { Vegetation } \\
\text { Status }\end{array}$ & $\begin{array}{l}\text { Grass, shrubs \& } \\
\text { trees in Dense } \\
\text { wood lands. }\end{array}$ & $\begin{array}{l}\text { Stocked with NTFP/ } \\
\text { timber species. }\end{array}$ & $\begin{array}{l}\text { Mod. Stocking } \\
\text { with NTFP/ timber } \\
\text { species. }\end{array}$ & $\begin{array}{l}\text { Well stocked with } \\
\text { NTFP/ timber } \\
\text { species. }\end{array}$ & $\begin{array}{l}\text { Dominantly } \\
\text { NTFPs with } \\
\text { some timber } \\
\text { species. }\end{array}$ & $\begin{array}{l}\text { Stocked } \\
\text { with freq/ } \\
\text { common } \\
\text { NTFP/ } \\
\text { timber. }\end{array}$ & $\begin{array}{ll}\text { Mod. } & \\
\text { Stocking } & \text { of } \\
\text { NTFPs } & \& \\
\text { timber } & \\
\text { species. } & \end{array}$ & $\begin{array}{l}\text { Valuable } \\
\text { timber/ } \\
\text { NTFP } \\
\text { species. }\end{array}$ \\
\hline & $\begin{array}{l}\text { LAND } \\
\text { UNIT }\end{array}$ & $\begin{array}{l}\text { Mountain slopes, } \\
\text { steep valleys }\end{array}$ & Gently undulating. & Level land. & Level land. & Level land. & Level land. & Level land. & Level land. \\
\hline & $\begin{array}{c}\text { SOIL/ } \\
\text { AGRIC } \\
\text { POTENTIA } \\
\text { L }\end{array}$ & $\begin{array}{lr}\text { High } & \text { Fertility } \\
\text { Soils; } & \text { cultivated } \\
\text { lands; } & \text { Erosion } \\
\text { prone. } & \end{array}$ & $\begin{array}{l}\text { Fertility/ Mod. Fertile } \\
\text { soils; Cultivated fields. }\end{array}$ & $\begin{array}{l}\text { Mod. Fert soils; } \\
\text { Prime lands for } \\
\text { cultivation. }\end{array}$ & $\begin{array}{l}\text { High/ mod fertility } \\
\text { soils; cultivable } \\
\text { lands. }\end{array}$ & $\begin{array}{l}\text { Fertile soils; } \\
\text { cultivable lands. }\end{array}$ & $\begin{array}{l}\text { Mod. } \\
\text { Fertility } \\
\text { soils; } \\
\text { cultivable } \\
\text { lands. }\end{array}$ & $\begin{array}{l}\text { Mod. } \\
\text { Fertility } \\
\text { soils; } \\
\text { cultivable } \\
\text { fields. }\end{array}$ & $\begin{array}{l}\text { Fertile soils; } \\
\text { cultivable } \\
\text { fields. }\end{array}$ \\
\hline
\end{tabular}

SOURCE: AUTHOR'S FIELD SURVEY, 2000-2002 
The areas for agricultural expansion are largely within high forest areas, savannas or climax secondary forest zones (TABLE 4). They are also largely within the level lands and in areas with high to moderately fertile soils. In Okorshie community however, the productive level lands have been used up, leaving agricultural expansion areas to the high hills and mountain slopes (Table 4), which nevertheless, represents the best of what is left for the purpose. One criticism of the area located for the farm expansion is the use of high forestlands rather than fallows, which are usually in abundance. The open access resource use regimes governing land acquisition in common lands and entrenched cultural habits are largely responsible for the use of forestlands for agricultural expansion.

\section{CONCLUSION}

Communities are evolving land use plans for sustainable community forest management. Community land use decisions have a lot of commonalities despite some differences which revolves generally around environmental protection considerations with sizeable allocations to community forest reserves, economic utility considerations with reasonable allocations made to timber harvesting and the development of multipurpose trees and forest plantations, and food security considerations with farm expansion areas having the largest allocations in the land use plan outside areas presently used for farming. On the basis of biophysical considerations and the socioeconomic realities of the communities, the land use planning decisions can be generally considered rational and may constitute a valid basis for community forestry management. 


\section{REFERENCES}

1. Ajai, Olawale (1999) 'The Role of Legislation in Land Use Planning', in Evolving An Effective Agricultural Land Use Policy For Nigeria, Abuja: Federal Ministry of agriculture and National Resources, Abuja.

2. Alden- Wily, Liz et al. (2001) 'Community Management of Forest in Tanzania Forest’ Trees \& People Newsletter 42 36- 45.

3. Atte, David (1996) 'ODA'S Review of Participatory Forest Management: The Experience of Cross River State, Nigeria, Unpublished report, Kumasi: NRI.

4. Benjamin, Mwasi (2001) 'Land Use Conflicts Resolution in a Fragile Ecosystem Using Multi-Criteria Evaluation (MACE)) And A GIS-Based Decision Support System (DSS)'. Paper Presented at the 2001 International Conference on Spatial Information for Sustainable Development, Kenya 2 - 5 October.

5. Bisong Francis (1998) 'Three-Model Community Participation in Forest Management in Cross River State' Unpublished report, Calabar: Forestry Development Department.

6. BSP (1993) African Biodiversity: Foundation for the Future. A framework for Integrating Biodiversity Conservation and Sustainable Development Biodiversity Support Program, USA.

7. Dunn, Robert et al (1994) 'Reconnaissance inventory of high forest and swamp forest areas in Cross River State, Nigeria' Unpublished report, Calabar:. FDD and CRSFP.

8. FAO, (2002) 'The Progress of Participatory Forestry In Africa' Unpublished report, FAO Forestry Policy and Institution Branch.

9. FDD (1994) 'A Strategy for Sustainable Development, Conservation $\&$ Management of the Forest of Cross River State' Unpublished report, Calabar: FDD and CRSFP.

10. Flasse, Stéphane et al (2002) 'Rapid appraisal of forest resources from remotely sensed data in Cross River State, Nigeria'. Unpublished, Calabar: Final Report CRSCFP, ERM \& DFID.

11. FRS (1998) 'Nigeria: Cross River State forest management plan. Forest Resources Study’ Unpublished report, Abuja: FORMECU.

12. Igugu, O. (1999) 'Land Use Plan for Nigeria,' in Evolving An Effective Agricultural Land Use Policy for Nigeria, Abuja: Federal Ministry of Agriculture and Natural Resources. 
13. Nolan, Timothy (2001) 'Community based forest management: Commercial harvesting of the rainforest of Indonesia', The International Forestry Review. 3 (3): 231-235.

14. Sprung, Rolf-Dieter. and Huss, Jurgen. (1998) 'Participatory Land Us Planning in Thailand - Conflict Potentials in Project Planning and Implementation' available at www.sefut.uni-freiburg.de/rolf.htm (accessed 8 July 2003).

15. Umans, Laurent. (1998) 'Participatory Process Analysis', Forests, Tress and People Newsletter 35:22-30.

\title{
POLITICS AND DEVELOPMENT
}

\section{Socialism in the Philosophy of Kwame Nkrumah}

\author{
Akomolafe \\ Akinola Mohammed
}

\begin{abstract}
This paper is a critical presentation of Kwame Nkrumah's socio-political theory of socialism as it affects Africans. The thesis of the paper is that Socialism is the only viable way forward for the newly-emerging African countries.. The paper shows that Nkrumah's reflections on socialism were genuine provocations and impetus to the development of scholarship and socio-political theory. The paper also shows that most of the critical reactions to Nkrumah's postulations and practice of socialism stem from misrepresentations of his views and actions. It is hoped that by clarifying some confusions and correcting some misrepresentations, this paper will contribute to a better understanding of Nkrumah's socialism.
\end{abstract}

